\title{
In Vitro Cellular Responses of Human Dental Primary Cells to Dental Filling Restoratives
}

\author{
Jun Sun ${ }^{1}$, Yiming Weng ${ }^{2}$, Fengyu Song ${ }^{1}$, Dong $\mathrm{Xie}^{2^{*}}$ \\ ${ }^{1}$ Department of Oral Biology, School of Dentistry, Indiana University, Bloomington, USA; ${ }^{2}$ Department of Biomedical Engineering, \\ Purdue School of Engineering and Technology, Indiana University-Purdue University Indianapolis, Indianapolis, USA. \\ Email: ${ }^{\mathrm{d}} \mathrm{dxie} @$ iupui.edu
}

Received March 29 $9^{\text {th }}$ 2011; revised April 20 2011 ; accepted May $8^{\text {th }}, 2011$.

\begin{abstract}
In vitro cytotoxicity of six contemporary commercial dental filling restoratives on human dental primary cells, pulp cells (HPCs) and human gingival fibroblasts (HGFs), were tested using WST-1 assay. Continuous $3 T 3$ mouse fibroblast cell lines were used for comparison. The results show that conventional glass-ionomer cement (GIC) Fuji II is not cytotoxic to all the cells. Resin-modified GIC (RMGIC) Fuji II LC is not cytotoxic to both HPCs and HGFs but cytotoxic to $3 T 3$ cells. RMGIC Vitremer and resin composite Z100 are very cytotoxic to all the cells. Resin composite P60 is cytotoxic but much less cytotoxic than Z100. Polycarboxylate cement Durelon is the most cytotoxic among the six tested materials. It was found that continuous $3 T 3$ cell lines were more vulnerable to leachable cytotoxic components than primary HPCs and HGFs. It was also found that the cytotoxcity of the tested materials was dose-dependent.
\end{abstract}

Keywords: In Vitro Cytotoxicity, Human Pulp Cells, Human Gingival Fibroblasts, 3 T3 Mouse Fibroblast Cells, Dental Cement, Resin Composite

\section{Introduction}

The biological compatibility of dental materials is of paramount importance to avoid or limit pulp tissue irritation and inflammation as well as surrounding gingival tissue inflammation as well as allergic contact dermatitis [1-3]. It has been shown that components of dental restoratives can be released into the oral cavity [4] and cause adverse effects such as mucosal irritation, epithelial proliferation, oral lichenoid reaction, hypersensitivity and anaphylactoid reactions [5]. The released components from polymerized resin-based dental materials include residual or unreacted monomers, initiators, activators and other additives [3,6,7]. The resin-based dental materials include resin composites $[9,10]$, dental bonding agents [11], resin-modified glass-ionomer cements (RMGICs) [3], conventional GICs (CGICs) [1-3], and other dental cements [12]. Among all these dental restoratives, CGICs are considered to be one of the most biocompatible restoratives $[3,12]$. On the other hand, RMGICs are less biocompatible due to release of unreacted monomers and other components [3]. Dental resin composites, a current substitute for dental amalgam, are applied in posterior cavity filling (stress-bearing sites), anterior teeth repair and core-building up restoration, due to their high-strength and high-wear-resistant nature [13-15]. However, their biocompatibility is somehow still in question and debate due to release of unreacted monomers, oligomers and other low molecular weight components.

There are many ways to conduct a biocompatibility or cytotoxicity test $[12,13]$. In vitro cytotoxicity tests, a screening test, are efficient and relatively inexpensive to conduct although they are not as accurate as in vivo animal usage tests $[12,13]$. Cell culture studies are frequently used to assess the in vitro cytotoxicity of resinbased materials, their elutes, or components (such as monomers or oligomers) $[6,16]$. So far there have been numerous publications regarding in vitro cytotoxicity of various dental materials [12,17]. Some of them have been focused on evaluating the cytotoxicity of the pure monomers and oligomers $[12,17]$ and the other on testing the cytotoxicity of the eluates of the materials $[7,8,12$, $17,18]$. All the published results have made useful contributions to the area of biocompatibility of dental restoratives $[5,12,17,18]$.

This study reports the evaluation of the in vitro cytotoxicity of six commercially available filling materials on two dental primary cells from human pulp and human 
gingival tissues by testing the eluates using WST-1 assay. The 3T3 mouse fibroblast cell lines were evaluated for comparison. The effect of the eluate concentration on the cytotoxicity was studied as well.

\section{Materials and Methods}

\subsection{Materials}

Fuji II (conventional glass-monomer cement) and Fuji II LC (light-cured glass-monomer cement) were used as received from GC America Inc (Alsip, IL). Durelon (zinc polycarboxylate cement), Vitremer (light-cured glassmonomer cement), Filtek Z100 (light-cured composite resin) and Filtek P60 (light-cured composite resin) were purchased from 3M ESPE (St. Paul, MN). The detailed information regarding the materials and their compositions are described in Table 1.

\subsection{Preparation of Specimens}

Cylindrical specimens of the materials used in this study were prepared at room temperature in glass tubing molds with dimensions of $4 \mathrm{~mm}$ in diameter by $2 \mathrm{~mm}$ in length [19]. A two-component (glass powder and liquid) system for Fuji II, Fuji II LC, Vitremer and Durelon and a single syringe (paste) system for Z100 and P60 were used and their specimens were prepared per manufacturers' instructions. For Fuji II and Durelon, specimens were prepared by thoroughly mixing glass powder and polymer liquid at a ratio of 2.7 and 2.0, respectively, followed by placing in the mold, conditioning in $100 \%$ humidity for $15 \mathrm{~min}$, removing from the mold and immediately sterilizing with $70 \%$ alcohol. For Fuji II LC and Vitremer, specimens were prepared by thoroughly mixing glass powder and polymer liquid at a ratio of 3.2 and 2.5 , respectively, followed by placing in the mold, exposing to blue light (EXAKT 520 Blue Light Polymerization Unit, $9 \mathrm{~W} / 71$, power $=30$, WGmbH, Germany) for $2 \mathrm{~min}$, conditioning in $100 \%$ humidity for $15 \mathrm{~min}$, removing from the mold and immediately sterilizing with 70\% alcohol. For Z100 and P60, specimens were prepared by placing the premixed paste from the product syringe into the mold, followed by exposing to blue light for $2 \mathrm{~min}$, conditioning in $100 \%$ humidity for $15 \mathrm{~min}$, removing from the mold and immediately sterilizing with $70 \%$ alcohol.

\subsection{Preparation of Eluates of the Test Materials}

Immediately after removing form the molds, the specimens were quickly rinsed with $70 \%$ ethanol and sterile phosphate buffer saline (PBS), followed by immersing in a 48-well plate containing $300 \mu \mathrm{l}$ serum minus DMEM (Dulbecco's modified Eagle's medium or DMEM, Hyclone Laboratories, Inc. Logan, UT) in a humidified incubator at $37^{\circ} \mathrm{C}$ with $5 \% \mathrm{CO}_{2}$ and $95 \%$ air for 1,3 and 7 days, for preparation of eluates. The surface area to volume ratio was $1 \mathrm{~cm}^{2} / \mathrm{ml}$, which was set according to the ISO standards $\left(0.5-6.0 \mathrm{~cm}^{2} / \mathrm{ml}\right)[20]$. Five specimens of each material for every eluate preparation were prepared and used for statistical analysis.

\subsection{Cell Culture Preparation}

Human pulp cells (HPCs) were isolated from the pulp tissue of healthy young permanent teeth undergoing orthodontic treatment, following the published protocol [21]. Briefly, the extracted teeth were cleaned consecutively with sterile PBS, $70 \%$ ethanol and PBS, followed by cutting to obtain the pulp tissues. The tissues were then placed in a culture dish and minced to small pieces. Human gingival fibroblasts (HGFs) were cultured from the gingival connective tissue of clinically healthy human subjects undergoing crown-lengthening surgery, following the published protocol [22]. Briefly, the tissues obtained from the clinics were treated consecutively with sterile PBS, 70\% ethanol and PBS. The tissues were then placed in a culture dish and minced to small pieces. $\mathrm{Balb} / \mathrm{c}$ 3T3 mouse fibroblast cells were obtained directly from the American Type Culture Collection (Manassas, VA).

All the three cells were then cultured at $37^{\circ} \mathrm{C}$ in an air atmosphere containing $5 \% \mathrm{CO}_{2}$ and $95 \%$ relative humidity, with DMEM containing low glucose, supplemented with $10 \%$ heat-inactivated fetal bovine serum (Hyclone Laboratories), $4 \mathrm{mM}$ L-glutamine (Hyclone Laboratories), $100 \mathrm{U} / \mathrm{ml}$ penicillin (Sigma-Aldrich, St. Louis, MO), 50 $\mu \mathrm{g} / \mathrm{ml}$ gentamicin (Invitrogen Life Technologies, Carls$\mathrm{bad}, \mathrm{CA}$ ) and $2.5 \mu \mathrm{g} / \mathrm{ml}$ amphotericin B fungizone (Lonza, Walkersville, MD). Either HPCs or HGFs which grew out of the explants were sub-cultured and maintained. Both HPCs and HGFs used for this study were taken between passage 3 and 8 .

\subsection{Evaluation of Cytotoxicity Using WST-1 Assay}

The water soluble tetrazolium salt-1 (WST-1) test was performed as described elsewhere [23]. Briefly, the cells were plated in a 96-well plate at $2 \times 10^{3}$ cells per well in $100 \mu \mathrm{l}$ of DMEM supplemented with $10 \%$ FBS, 100 $\mathrm{U} / \mathrm{ml}$ penicillin and $100 \mu \mathrm{g} / \mathrm{ml}$ streptomycin. After incubation at $37^{\circ} \mathrm{C}$ overnight, the medium was replaced with $100 \mu \mathrm{l}$ of the fresh medium containing different concentrations of eluate $(0 \%, 10 \%, 20 \%, 40 \%, 60 \%$ and $80 \%)$. The cells were then incubated for $72 \mathrm{~h}$ before WST testing. The positive control was serum minus DMEM with untreated cells and the negative control was serum minus DMEM without cells. The WST-1 test was conducted by adding $10 \mu \mathrm{l}$ of WST-1 reagent (Roche Diagnostics, Indianapolis, IN) and $90 \mu 1$ of serum minus DMEM into a 
well and then incubating the plate at $37^{\circ} \mathrm{C}$ for $2 \mathrm{~h}$. The absorbance of the solution was measured at $450 \mathrm{~nm}$ using a microplate reader (Molecular devices, Sunnyvale, CA). Cell viability (\%) was obtained by the equation: cell viability $(\%)=($ absorbance of the sample elaute - absorbance of the negative control)/(absorbance of the positive control - absorbance of the negative control) $\times 100 \%$. Cell morphology was obtained at 100X magnification using Nikon eclipse TS100 microscope (Nikon Corp., Japan).

\subsection{Statistical Analysis}

One-way analysis of variance (ANOVA) with the post hoc Tukey-Kramer multiple range test was used to determine significant differences of in vitro cytotoxicity among the materials. A level of $\alpha=0.05$ was used for statistical significance.

\section{Results and Discussion}

Biocompatibility of dental restoratives is very important in dentistry [1-3]. Non-biocompatible or cytotoxic materials can cause short-term or long-term tissue inflammation or cell death [1-5]. Regarding dental cavity restoratives, the most critical concern for biocompatibility is the cytotoxcity caused by the leachable components such as unreactive monomers, residual initiators and other residual additives form the organic resins or cytotoxic metal ions from the inorganic fillers. In this study, we evaluated six contemporary dental filling restoratives including Fuji II, Fuji II LC, Vitremer, P60, Z100 and Durelon. Their compositions are shown in Table 1 [24-30]. It is known that chemistry and potentially leachable components ultimately determine the cytotoxicity of the filled restoratives [1-4]. Let's first describe the chemistry involved in the setting reactions of the six tested materials as well as discuss the potential leachable species and then discuss the results from this research.

\subsection{Chemistry Involved in the Setting Reactions of the Tested Materials and Potential Leachable Species}

\subsubsection{Durelon}

Durelon is a chemically-cured dental luting cement. It is composed of zinc oxide, zinc fluoride, polycarboxylic acid and water. An acid-base reaction between zinc cations released from a $\mathrm{ZnO} / \mathrm{ZnF}_{2}$ glass and carboxyl anions pendent on polycarboxylic acid describes the setting reaction mechanism in Durelon [13,31]. During the setting reaction, with the help of water the surface of the $\mathrm{ZnO} / \mathrm{ZnF}_{2}$ glass particles reacts with the carboxyl groups pendent from polycarboxylate to form zinc carboxylate salt-bridges and hardens the cement. It is known that not all the glass particles participate in the setting reaction [13]. Therefore, the unreacted zinc cations can leach out of the cement. The polycarboxylic acid is hardly leachable due to its high molecular weight (MW) $[3,13]$.

\subsubsection{Fuji II}

Fuji II is a chemically-cured glass-ionomer cement (GIC) used for dental luting and filling purposes. It is composed of calcium aluminofluorosilicate glass powder, polycarboxylic acid (a copolymer of acrylic acid and itaconic acid), tartaric acid (TA) and water, where TA is used for extending the working time. An acid-base reaction between calcium as well as aluminum cations released from a reactive sintered glass and carboxyl anions pendent on polyacid describes the setting mechanism in conventional GIC [32]. During the setting reaction, with the help of water the surface of the sintered glass particles reacts with the carboxyl groups pendent on polycarboxylate to form three-dimensional aluminum-carboxylate/calciumcarboxylate salt-bridges and hardens the cement. The polymer is hardly leachable. Although not all the glass particles participate in the setting reaction, the unreacted glass particles do not easily leach out of the cement be-

Table 1. Information related to the materials used in this study.

\begin{tabular}{|c|c|c|c|c|}
\hline Material & Type & Setting Mode & Liquid Composition ${ }^{1}$ (by weight) & Glass Composition (by volume) \\
\hline Durelon & Polycarboxylate cement & Chemically cured & PAA, water & Zinc oxide/zinc fluoride powder \\
\hline Fuji II & Conventional GIC & Chemically cured & PAAIA, water, tartaric acid & Ca-AI-F silicate glass powder \\
\hline Fuji II LC & Resin-modified GIC & Light-cured & TEGDMA, HEMA, PAA, water, CQ, DMAEMA & Sr-AI-F silicate glass powder \\
\hline Vitremer & Resin-modified GIC & Light-cured & $\begin{array}{l}\text { HEMA, PAA-g-IEM, water, tartaric acid, CQ, DC, } \\
\qquad \mathrm{K}_{2} \mathrm{~S}_{2} \mathrm{O}_{8} \text {, ascorbic acid }\end{array}$ & Al-F silicate glass powder \\
\hline P60 & Composite resin & Light-cured & BisGMA, UDMA, BisEMA, CQ, DMAEMA & $61 \% \mathrm{ZrO}_{2}-\mathrm{SiO}_{2}$ filler \\
\hline $\mathrm{Z} 100$ & Composite resin & Light-cured & BisGMA, TEGDMA, CQ, DMAEMA & $66 \% \mathrm{ZrO}_{2}-\mathrm{SiO}_{2}$ filler \\
\hline
\end{tabular}

${ }^{1}$ PAA $=$ poly (acrylic acid), PAAIA = poly(acrylic acid-co-itaconic acid), TEGDMA = triethylene glycol dimethacrylate, HEMA = 2-hydroxyethyl methacrylate, $\mathrm{CQ}=$ camphorquinone, DMAEMA = N,Ndimethylaminoethyl methacrylate, PAA-g-IEM = poly(acrylic acid) grafted with 2-isocyanatoethyl methacrylate, DC $=$ diphenyliodonium chloride, BisGMA $=$ Bisphenol A glycidyl dimethacrylate, BisEMA $=$ Bisphenol A polyethylene glycol diether dimethacrylate, and $\mathrm{UDMA}=$ urethane dimethacrylate. 
cause they are sintered $[32,33]$.

\subsubsection{Fuji II LC}

Fuji II LC is a light-cured resin-modified GIC (RMGIC) mainly used for cavity filling and core-building purposes. It is composed of strontium aluminofluorosilicate glass powder, 2-hydroxylethyl methacrylate (HEMA), triethylene glycol dimethacrylate (TEGDMA), poly(acrylic acid), water, camphorquinone (CQ) and dimethylaminoethyl methacrylate (DMAEMA), where CQ and DMAEMA are used for initiating the photo polymerization. Except for the acid-base reaction similar to that in Fuji II, HEMA and TEGDMA can copolymerize to form a crosslinked network via covalent bond formation upon blue light initiation. This polymer network is somehow stronger than that formed by salt-bridges in Fuji II, especially in toughness and tensile strength $[13,29]$. However, unreacted HEMA as well as TEGDMA due to the limited conversion in situ [12] and CQ as well as DMAEMA may possibly leach out of the cement. The sintered glass particles, like the glass in Fuji II, usually do not easily leach out from Fuji II LC [33].

\subsubsection{Vitremer}

Vitremer is a tri-cured RMGIC mainly used for dental luting. It contains aluminofluorosilicate glass powder, HEMA, poly(carboxylic acid) with pendent methacrylate groups, TA, water, potassium persulfate $\left(\mathrm{K}_{2} \mathrm{~S}_{2} \mathrm{O}_{8}\right)$, ascorbic acid, $\mathrm{CQ}$ and diphenyliodonium chloride (DC), where TA, $\mathrm{K}_{2} \mathrm{~S}_{2} \mathrm{O}_{8}$, ascorbic acid, CQ and DC are used for adjusting the working time and initiating the redox as well as photo polymerizations. Except for the acid-base and photo polymerization reactions shown in Fuji II LC, there also exists a redox polymerization initiated by a pair of redox initiators $\mathrm{K}_{2} \mathrm{~S}_{2} \mathrm{O}_{8}$ and ascorbic acid. The photo-activator used in Vitremer is also different from that used in Fuji II LC, i.e., Vitremer uses DC but Fuji II LC uses DMAEMA instead [6,29]. Furthermore, Vitremer uses HEMA and polycarboxylic acid with pendent methacrylate groups to form a crosslinked polymer network via both photo- and redox-initiated polymerizations [6, 29]. Like those in Fuji II and Fuji II LC, the sintered glass particles usually do not leach out [33]. The potential leachable components in Vitremer include unreacted HEMA, CQ, DC, TA, $\mathrm{K}_{2} \mathrm{~S}_{2} \mathrm{O}_{8}$ and ascorbic acid.

\subsubsection{Z100 and P60}

$\mathrm{Z} 100$ is a light-cured resin composite for cavity filling. It contains $\mathrm{ZrO}_{2}-\mathrm{SiO}_{2}$ fillers, bisphenol A diglycidyl ether dimethacrylate (BisGMA), TEGDMA, CQ and DMAEMA, where CQ and DMAEMA are used for initiating the photo polymerization. P60 is also a light-cured resin composite but it is an improved version of Z100. In $\mathrm{P} 60$, except for $\mathrm{ZrO}_{2}-\mathrm{SiO}_{2}$ fillers, BisGMA, CQ and
DMAEMA, TEGDMA is replaced by a mixture of urethane dimethacrylate (UDMA) and bisphenol A polyethylene glycol diether dimethacrylate (BisEMA). It is claimed to have lower shrinkage as well as reduced aging and be more hydrophobic as well as less sensitive to changes in atmospheric moisture. Upon the photo initiation the dimethacrylate oligomers in the formulations lead to formation of the crosslinked polymer networks. Unlike those in either GICs or zinc polycarboxylate cement, the glass particles in resin composites are only used as fillers and do not participate in any chemical reactions. They are usually inert to cells or tissues $[12,13]$. The difference between Z100 and P60 lies in that the former contains TEGDMA but the latter contains UDMA and BisEMA. Due to higher MWs of UDMA and BisEMA, the resin liquid in the P60 formulation is more viscous. P60 is also claimed to have lower shrinkage as well as reduced aging and be more hydrophobic as well as less sensitive to changes in atmospheric moisture. The potential leachable components in Z100 are TEGDMA, CQ and DMAEMA whereas those in P60 are UDMA, BisEMA, CQ and DMAEMA. The unreacted BisGMA (if any) is hardly leachable due to its higher hydrophobicity and MW.

\subsection{Results and Discussion on in Vitro Cytotoxicty Testing}

Three types of cells, HPCs, HGFs and 3 T3 mouse fibroblasts, were used to evaluate the cytotoxicity of the six materials. HPCs and HGFs, respectively, were isolated directly from pulp tissues of human teeth and gingival connective tissues of human subjects whereas 3T3 fibroblasts were cultured continuous cell lines. As compared to $3 \mathrm{~T} 3$ cells, HPCs and HGFs are more clinically relevant. In this study, the WST-1 assay was used as a tool to evaluate the cytotoxicity. The WST-1 is a colorimetric assay based on the cleavage of the water soluble tetrazolium salt (WST-1) by mitochondrial dehydrogenases to a yellow-orange formazan and is claimed to be a more sensitive assay than MTT [23].

Figure 1(a) shows the HPC viability after the cells were cultured with the eluates of the six materials at a concentration of $80 \%$. Fuji II and Fuji II LC showed the highest cell viability, respectively, after cell exposure to 1-, 3- and 7-day eluates. Durelon showed the lowest viability. The viability (\%) was in the decreasing order: 1$)$ for the 1-day eluate, Fuji II $(100.3 \pm 6.3)>$ Fuji LC $(88.0$ $\pm 11)>\mathrm{P} 60(54.2 \pm 7.2)>$ Vitremer $(37.9 \pm 3.8)>\mathrm{Z} 100$ $(12.4 \pm 2.7)>$ Durelon $(0.19 \pm 0.3)$, where Z100 and Durelon, Fuji II and Fuji II LC, and Vitremer and P60 were not significantly different from each other $(p>$ $0.05)$; 2) for the 3-day eluate, Fuji LC $(105.9 \pm 10.3)>$ Fuji II $(98.8 \pm 7.8)>$ P $60(50.7 \pm 3.6)>$ Vitremer $(27.1 \pm$ 
5.3) $>$ Z100 $(6.82 \pm 3.7)>$ Durelon $(0.39 \pm 0.9)$, where Z100 and Durelon as well as Fuji II and Fuji II LC were not significantly different from each other $(p>0.05) ; 3)$ for the 7-day eluate, Fuji II $(101.2 \pm 11.3)>$ Fuji II LC $(93.8 \pm 2.3)>\mathrm{P} 60(55.5 \pm 8.5)>$ Vitremer $(20.5 \pm 1.6)>$ Z100 $(3.65 \pm 0.8)>$ Durelon $(3.0 \pm 0.7)$, where Fuji II and Fuji II LC as well as Z100 and Durelon were not significantly different from each other $(p>0.05)$

Figure 1(b) shows the HGF viability at a concentration of $80 \%$. Fuji II showed the highest cell viability to all the three eluates. Durelon showed the lowest viability. The viability (\%) was in the decreasing order: 1) for the 1-day eluate, Fuji II LC $(88.5 \pm 6.2)>$ Fuji II $(84.0 \pm 8.3)$ $>$ P60 $(61.3 \pm 12.8)>$ Z100 $(15.9 \pm 0.4)>$ Vitremer $(7.0$ $\pm 0.1)>$ Durelon $(1.2 \pm 2.2)$, where Fuji II and Fuji II LC as well as Vitremer, Z100 and Durelon were not significantly different from one another $(p>0.05) ; 2)$ for the 3-day eluate, Fuji II LC $(88.8 \pm 11.7)>$ Fuji II $(88.1 \pm$ $8.1)>\mathrm{P} 60(57.9 \pm 14.8)>$ Vitremer $(11.3 \pm 1.3)>\mathrm{Z} 100$ $(7.4 \pm 2.6)>$ Durelon $(1.7 \pm 0.9)$, where Fuji II and Fuji II LC as well as Vitremer, Z100 and Durelon were not significantly different from one another $(p>0.05) ; 3)$ for the 7-day eluate, Fuji II $(83.3 \pm 9.6)>$ Fuji II LC $(80.7 \pm$ $5.3)>\mathrm{P} 60(57.3 \pm 4.0)>$ Vitremer $(12.9 \pm 3.1)>\mathrm{Z} 100$ $(5.1 \pm 3.5)>$ Durelon $(1.8 \pm 3.0)$, where Fuji II and Fuji II LC as well as Vitremer, Z100 and Durelon were not significantly different from one another $(p>0.05)$.

Figure 1(c) shows the 3T3 fibroblast viability at a concentration of $80 \%$. Fuji II showed the highest cell viability to the three eluates. Z100 showed the lowest viability. The viability (\%) was in the decreasing order: 1$)$ for the 1-day eluate (Figure 2(a)), Fuji II $(99.4 \pm 2.3)>$ P60 $(64.9 \pm 8.4)>$ Fuji II LC $(53.6 \pm 2.9)>$ Durelon $(2.63 \pm 2.6)>$ Vitremer $(0.78 \pm 0.7)>Z 100(0.47 \pm 1.9)$, where Vitremer, Z100 and Durelon were not significantly different from one another $(p>0.05) ; 2)$ for the 3-day eluate (Figure 2(b)), Fuji II $(100.8 \pm 5.5)>$ P60 $(70.4 \pm 6.1)>$ Fuji II LC $(68.0 \pm 3.3)>$ Vitremer $(4.89 \pm$ $0.3)>$ Durelon $(3.15 \pm 0.4)>Z 100(0.07 \pm 2.3)$, where Fuji II LC and P60 as well as Vitremer, Z100 and Durelon were not significantly different from each other $(p>$ $0.05)$; 3) for the 7-day eluate, Fuji II (94.4) > P60 (45.7 \pm $4.8)>$ Fuji II LC $(43.1 \pm 4.6)>$ Durelon $(2.4 \pm 1.7)>$ $\mathrm{Z} 100(0.5 \pm 0.023)>$ Vitremer $(0.18 \pm 2.1)$, where Fuji II LC and P60 as well as Vitremer, Z100 and Durelon were not significantly different from each other $(p>0.05)$.

From Figures 1(a)-(c), Fuji II was the most biocompatible restorative but Durelon was nearly the most cytotoxic one. The results are interpreted below with the help of the compositions and potential leachable species discussed in the previous section. For Fuji II, this cement simply consists of a sintered calcium aluminofluorosilicate glass powder, polycarboxylic acid, TA and water.

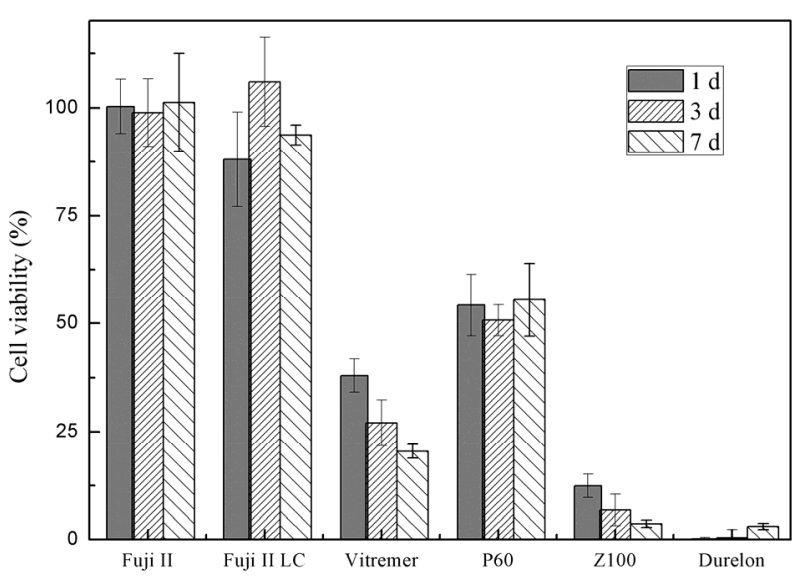

(a)

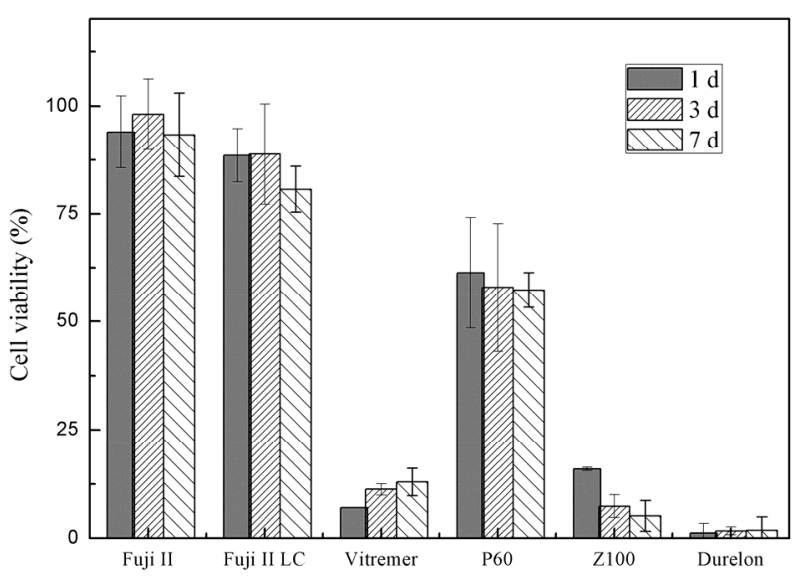

(b)

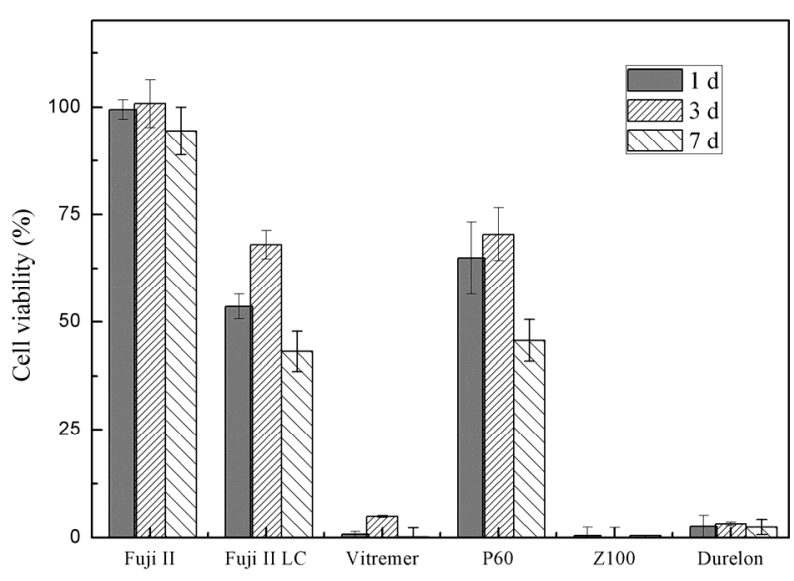

(c)

Figure 1. Cell viability comparison after cultured with the eluates from different cements for 72 h. (a) HPC viability; (b) HGF viability; (c) 3T3 fibroblast viability. Eluates were obtained from the 1-, 3- and 7-day incubation at a concentration of $80 \%$. 
During the initial setting, the $\mathrm{Al}^{3+}$ and $\mathrm{Ca}^{2+}$ react with $-\mathrm{COO}^{-}$groups. Although there may be a very small amount of $\mathrm{Al}^{3+}$ and $\mathrm{Ca}^{2+}$ ions leached, it would not possibly cause any significant cytotoxicity [33]. Meanwhile, there may be some leachable polycarboxylic acid and TA [34]; however, these acidic species would not possibly cause any significant cytotoxicity as well because the tested specimens were immersed in DMEM where these acidic species could be buffered. That is why Fuji II showed no cytotoxicity at all to all the cells. For Fuji II LC, this cement showed nearly no cytotoxicity to HPCs and HGFs but was cytotoxic to 3T3 cells. Except for the similar components shown in Fuji II, Fuji II LC also contains HEMA ( $30 \%-60 \%$ by weight), TEGDMA ( $1 \%$ - 5\%), CQ and DMAEMA. Among them, CQ and DMAEMA are considered to be the least toxic [7] and they are only used in $1 \%-2 \%[13,29]$. It was found that both HEMA and TEGDMA were cytotoxic and TEGDMA was even more cytotoxic than HEMA [6,7]. However, since Fuji II LC only contains a very small amount of TEGDMA and most of it was used to crosslink with HEMA, Fuji II LC showed a better biocompatibility than the other tested materials except for Fuji II. Furthermore, by comparing the cell viability results among HPCs, HGFs and 3T3 cells, we found that 3T3 cells seemed more sensitive to HEMA and TEGDMA (if any) than HPCs and HGFs. In other words, 3T3 cells responded more sensitively than either HPCs or HGFs. For Vitremer, we found that this cement was the most cytotoxic restorative among the three GICs tested. Except for the components shown in Fuji II and HEMA as well as CQ shown in Fuji II LC, Vitremer also contains polycarboxylic acid with pendent methacrylate groups, $\mathrm{K}_{2} \mathrm{~S}_{2} \mathrm{O}_{8}$, ascorbic acid and DC. DC has been reported to be the most cytotoxic component which is responsible for the cell death in Vitremer and Vitrobond [29]. Both DC and HEMA are the main possible reason to cause very low cell viability values $[6,7,29]$. In addition, similar to the results for Fuji II LC, HPCs and HGFs showed higher viability values than $3 \mathrm{~T} 3$ cells, indicating that $3 \mathrm{~T} 3$ cells are more vulnerable to both HEMA and DC. For Z100, this resin composite contains $\mathrm{ZrO}_{2}-\mathrm{SiO}_{2}$ fillers, BisGMA (approximately $50 \%$ by mole), TEGDMA (approximately $50 \%$ ), CQ (approximately 1\%) and DMAEMA (approximately $2 \%$ ). Except for CQ and DMAEMA, both BisGMA and TEGDMA were found to be very cytotoxic and BisGMA was even more cytotoxic than TEGDMA when testing in a DMSO/water mixture [7]. However, since BisGMA is more hydrophobic than TEGDMA $[7,12]$ and its $\mathrm{MW}(\mathrm{MW}=512)$ is also higher than that of TEGDMA (MW $=286$ ), the leaching probability of BisGMA in aqueous solution is much lower than that for TEGDMA. A substantial amount of TEGDMA in Z100 should be responsible for its high cytotoxicity. Furthermore, HPCs and HGFs seemed less vulnerable to Z100 than $3 \mathrm{~T} 3$ cells. The similar result was demonstrated elsewhere [18]. For P60, this resin composite was found not to be as cytotoxic as Z100. Except for the fillers, BisGMA, CQ and DMAEMA present in Z100, P60 does not contain TEGDMA but contains UDMA and BisEMA instead [27]. Because both UDMA (MW = 470) and BisEMA (MW $=540$ ) have higher MWs and are more hydrophobic than TEGDMA (MW $=286$ ), their mobility and aqueous solubility, respectively, should be slower and lower than TEGDMA. Although BisGMA, UDMA and BisEMA have been found to be more cytotoxic in the DMSO/water mixture than TEGDMA [7,12], TEGDMA is more leachable in aqueous solution or culture medium than the other two due to its lower MW and higher hydrophilicity. That is probably why P60 showed considerably lower cytotoxicity than Z100. For Durelon, this is a dental luting cement and its setting chemistry is very similar to most conventional GICs such as Fuji II. Except for polycarboxylic acid and water, Durelon uses zinc oxide and zinc fluoride as a reactive glass in its system. Zinc cations have been found to be very cytotoxic in vitro and considered to be a dangerous cations to cells, unless combining with other cations such as $\mathrm{Fe}^{++}$or $\mathrm{Ca}^{++}$ [35]. As mentioned earlier, polycarboxylic acid would not lead to much cytotoxcity from the cement due to buffering of the culture medium. However, leachable zinc cations especially from zinc fluoride could possibly cause significant cytotoxicity to surrounding cells or tissues. Apparently the zinc-con- taining cement Durelon showed the highest cytotoxcity to all the cells among all the six materials.

Figures 2(a) and (b) show the HPC viability vs. eluate concentration at the 1-day and 7-day extractions, respectively. For the 1-day eluate, Fuji II showed no cytotoxicity at all; Fuji II LC showed nearly no cytotoxicty; Vitremer, P60, Z100 and Durelon started to show the cytotoxicty, respectively, at a concentration of $20 \%, 80 \%$, $40 \%$ and $40 \%$, with the viability values of $80 \%, 54 \%$, $66 \%$ and $4.8 \%$. For the 7 -day eluate, both Fuji II and Fuji II LC showed no cytotoxicity; Vitremer, P60, Z100 and Durelon started to show the cytotoxicty, respectively, at a concentration of $10 \%, 20 \%, 10 \%$ and $40 \%$, with the viability values of $59 \%, 83 \%, 65 \%$ and $1.3 \%$.

Figures 3(a) and (b) show the HGF viability vs. eluate concentration at the 1-day and 7-day extractions, respectively. For the 1 day eluate, Fuji II and Fuji II LC showed nearly no cytotoxicity; Vitremer, P60, Z100 and Durelon started to show the cytotoxicty, respectively, at a concentration of $20 \%, 60 \%, 40 \%$ and $40 \%$, with the viability values of $62,80,63$ and $36 \%$. For the 7-day eluate, Fuji II showed no cytotoxicity; Fuji II LC showed slight cy- 


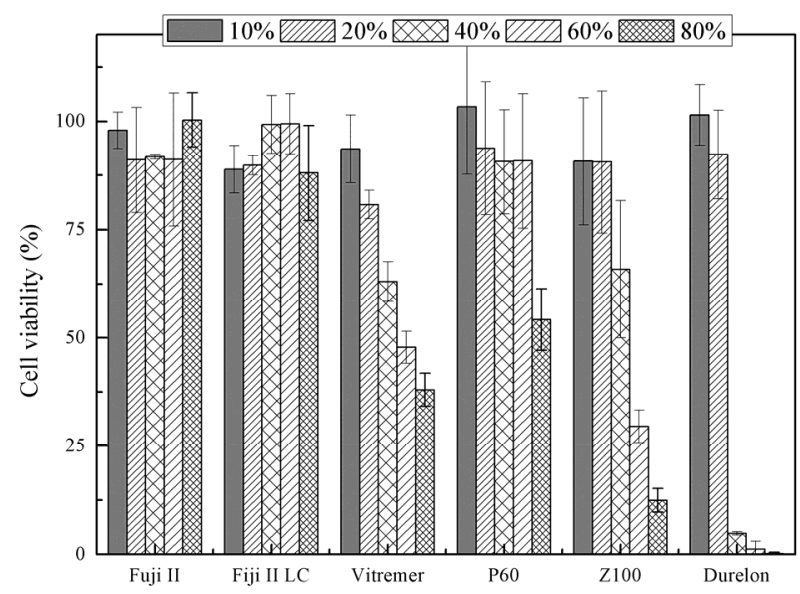

(a)

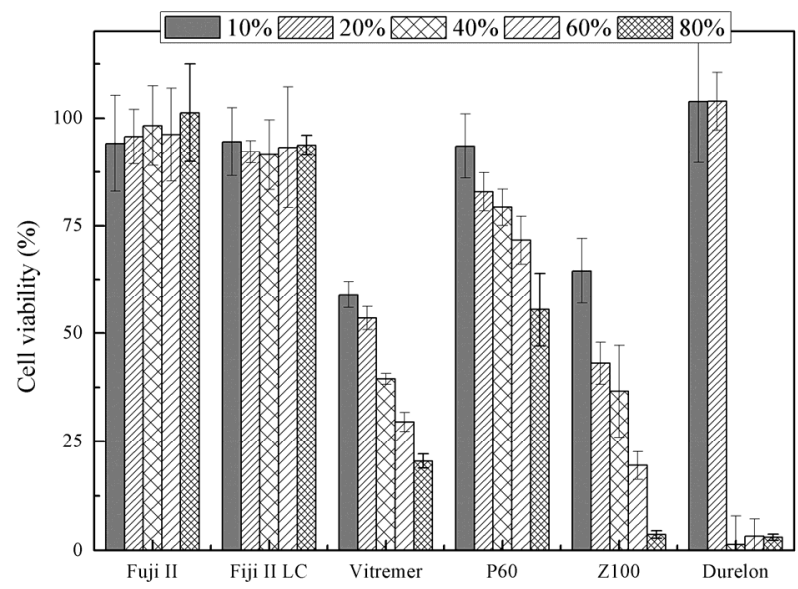

(b)

Figure 2. HPC viability (\%) vs. cement eluate concentration. (a) eluates obtained from the 1-day incubation; (b) eluates obtained from the 7-day incubation. The cells were incubated with the medium containing different concentrations of the eluates at $37^{\circ} \mathrm{C}$ for $72 \mathrm{~h}$ before WST-1 testing.

totoxicty at a concentration of 80 with the viability of $80 \%$; Vitremer, P60, Z100 and Durelon started to show the cytotoxicty, respectively, at a concentration of $10 \%$, $40 \%, 10 \%$ and $40 \%$, with the viability values of $52 \%$, $70 \%, 83 \%$ and $0.9 \%$.

Figures 4(a) and (b) show the 3T3 fibroblast viability vs. eluate concentration at the 1-day and 7-day extractions, respectively. For the 1 day eluate, Fuji II showed no cytotoxicity; Fuji II LC, Vitremer, P60, Z100 and Durelon started to show the cytotoxicty, respectively, at a concentration of $60 \%, 20 \%, 60 \%, 10 \%$ and $20 \%$, with the viability values of $82 \%, 70 \%, 77 \%, 62 \%$ and $36 \%$. For the 7-day eluate, Fuji II showed no cytotoxicity; Fuji II LC, Vitremer, P60, Z100 and Durelon started to show the cytotoxicty, respectively, at a concentration of $20 \%$, $10 \%, 20 \%, 10 \%$ and $10 \%$, with the viability values of

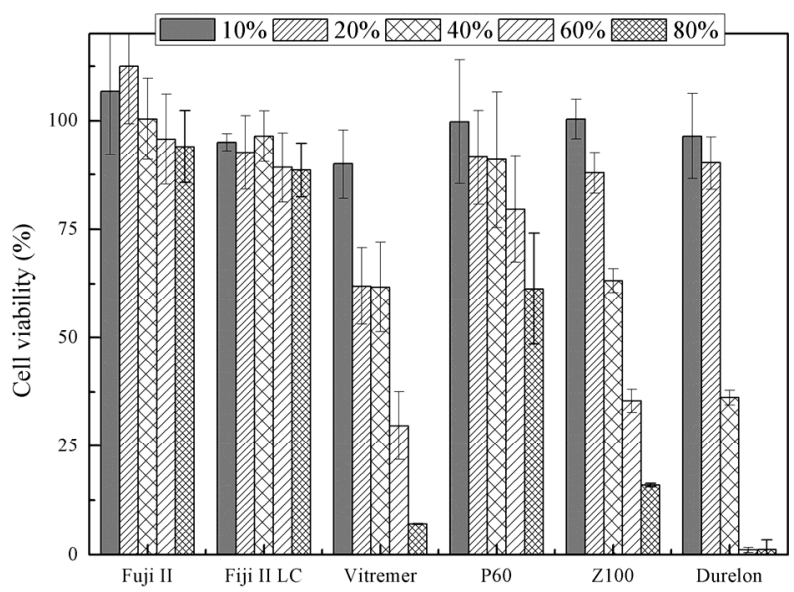

(a)

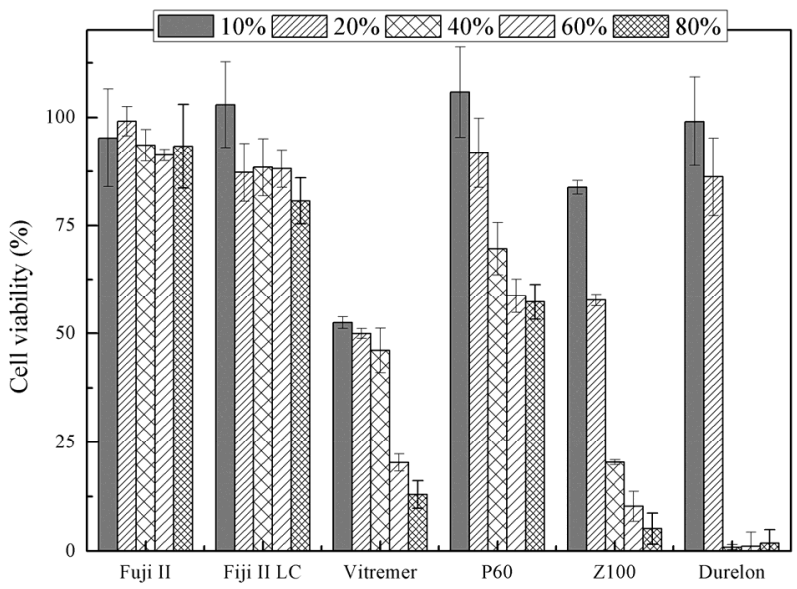

(b)

Figure 3. HGF viability (\%) vs. cement eluate concentration. (a) eluates obtained from the 1-day incubation; (b) eluates obtained from the 7-day incubation. The cells were incubated with the medium containing different concentrations of the eluates at $37^{\circ} \mathrm{C}$ for $72 \mathrm{~h}$ before WST-1 testing.

$70 \%, 60 \%, 79 \%, 35 \%$ and $59 \%$.

The results from Figures 2-4 clearly indicate that the cytotoxicity of the tested materials was dose- dependent, as reported elsewhere [36]. In the case of HPCs (Figure 2), Fuji II showed no cytotoxicity at all the eluate concentrations with both 1-day and 7-day extractions. Fuji II LC showed nearly no cytotoxicity at all the eluate concentrations. Vitremer started to show the cytotoxicity with the cell viability of $80 \%$ at $20 \%$ and $59 \%$ at $10 \%$ and ended up with $38 \%$ and $21 \%$ at $80 \%$ for the 1-day and 7-day eluates, respectively, suggesting that at the eluate concentration of $20 \%$ the leachable species in Vitremer started to kill the cells. P60 started to show the cytotoxcity with the cell viability of $54 \%$ at $80 \%$ for the 1-day eluate and $83 \%$ at $20 \%$ and $55 \%$ at $80 \%$ for the 7-day eluate, suggesting that the leachable species in P60 


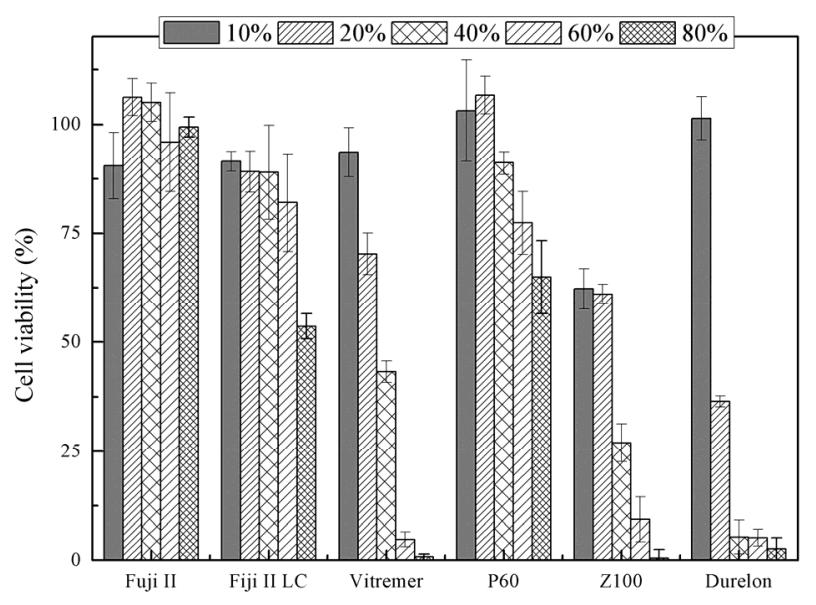

(a)

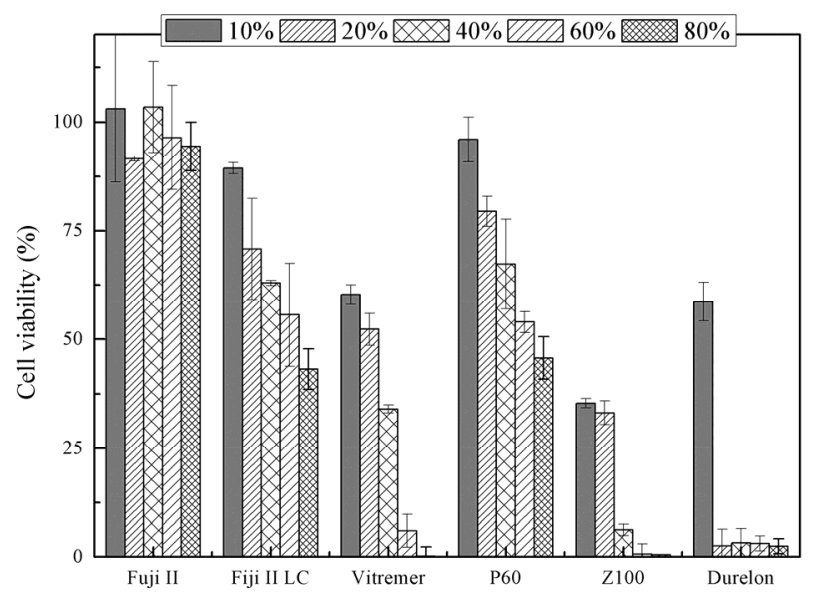

(b)

Figure 4. 3T3 fibroblast viability (\%) vs. cement eluate concentration: (a) eluates obtained from the 1-day incubation; (b) eluates obtained from the 7-day incubation. The cells were incubated with the medium containing different concentrations of the eluates at $37^{\circ} \mathrm{C}$ for $72 \mathrm{~h}$ before WST-1 testing.

release very slowly. Z100 started to show the cytotoxicity with the viability of $66 \%$ at $40 \%$ and $65 \%$ at $10 \%$ and ended with $12 \%$ and $3.6 \%$ at $80 \%$, suggesting that a large quantity of TEGDMA in Z100 lead to a higher cytotoxicity. Durelon started to show the cytotoxicity with the viability of $4.8 \%$ and $1.3 \%$ at $40 \%$ and ended up with $0.2 \%$ and $3.0 \%$ at $80 \%$. The results indicate that HPCs can tolerate the eluate concentration below $40 \%$ in Durelon. However, once reaching 40\%, the cells almost completely died, suggesting that above a certain concentration threadshold the zinc ions are deadly species to cells, unless it can be buffered or combined with other cations such as $\mathrm{Fe}^{++}$or $\mathrm{Ca}^{++}$[35].

Regarding HGFs (Figure 3), similar to HPCs, both Fuji II and Fuji II LC showed nearly no cytotoxicity at all the eluate concentrations. Vitremer started to show the cytotoxicity with the cell viability of $62 \%$ at $20 \%$ and $52 \%$ at $10 \%$ and ended up with $7 \%$ and $13 \%$ at $80 \%$ for the 1-day and 7-day eluates, respectively, suggesting that at the eluate concentration of $10 \%$ or $20 \%$ the leachable species in Vitremer started to kill the cells. P60 started to show the cytotoxcity with the cell viability of $80 \%$ at $60 \%$ and $70 \%$ at $40 \%$ and end up with $61 \%$ and $57 \%$ at $80 \%$, suggesting that the leachable species such as $\mathrm{Bi}$ sEMA and UGDMA in P60 release very slowly. Unlike P60, Z100 started to show the cytotoxicity with the viability of $63 \%$ at $40 \%$ and $83 \%$ at $10 \%$ and ended with $16 \%$ and $5.1 \%$ at $80 \%$, suggesting that a large quantity of TEGDMA leaching speeds up the cytotoxicity of Z100. Durelon started to show the cytotoxicity with the viability of $36 \%$ and $0.9 \%$ at $40 \%$ and ended up with $1.2 \%$ and $1.8 \%$ at $80 \%$, indicating that HGFs can tolerate the eluate concentration of Durelon below $40 \%$. The results for HFGs showed the same trend as those for HPCs.

Considering 3T3 cells (Figure 4), only Fuji II showed no cytotoxicity at all the eluate concentrations. Fuji II LC started to show the cytotoxicity with the cell viability of $82 \%$ at $60 \%$ and $70 \%$ at $20 \%$ and ended with $54 \%$ and $43 \%$ at $80 \%$, for the 1 -day and 3-day eluates, respectively. The results suggest that Fuji II LC is selectively cytotoxic to $3 \mathrm{~T} 3$ cells or continuous cell lines but not to human primary cells (see Figures 2 and 3). The results were consistent with those published elsewhere $[18,19]$. Vitremer started to show the cytotoxicity with the cell viability of $70 \%$ at $20 \%$ and $60 \%$ at $10 \%$ and ended with $0.8 \%$ and $0.2 \%$ at $80 \%$. By comparing with HPCs and HGFs, 3T3 is more vulnerable to Vitremer. P60 started to show the cytotoxicity with the cell viability of $77 \%$ at $60 \%$ and $79 \%$ at $20 \%$ and ended with $65 \%$ and $46 \%$ at $80 \%$. Z100 started to show the cytotoxicity with the viability of $62 \%$ and $35 \%$ at $10 \%$ and ended with $0.5 \%$ and $0.5 \%$ at $80 \%$. Durelon started to show the cytotoxicity with the viability of $36 \%$ at $20 \%$ and $59 \%$ at $10 \%$ and ended up with $2.6 \%$ and $2.5 \%$ at $80 \%$, indicating that $3 \mathrm{~T} 3$ cells can tolerate the eluate concentration of Durelon below $10 \%$ or $20 \%$. Comparing with HPCs and HGFs, 3T3 showed lower tolerance to Durelon.

Figure 5 is a set of optical photomicrographs describing the HPC morphology after contact with the corresponding 7-day eluate. Figures 5(a)-(g) represent the HPC morphology after cultured with blank, Fuji II, Fuji II LC, Vitremer, P60, Z100 and Durelon, respectively. In Figure 5(a) (control) and (b) (Fuji II), numerous healthy cells with an elongated and spindle shape (typical HPC morphology) are observed. In Figure 5(c) (Fuji II LC) and (e) (P60), some small black round spots (dead or unhealthy cells) are observed although there still exist many elongated and spindle shaped cells. In Figure 5(d) 


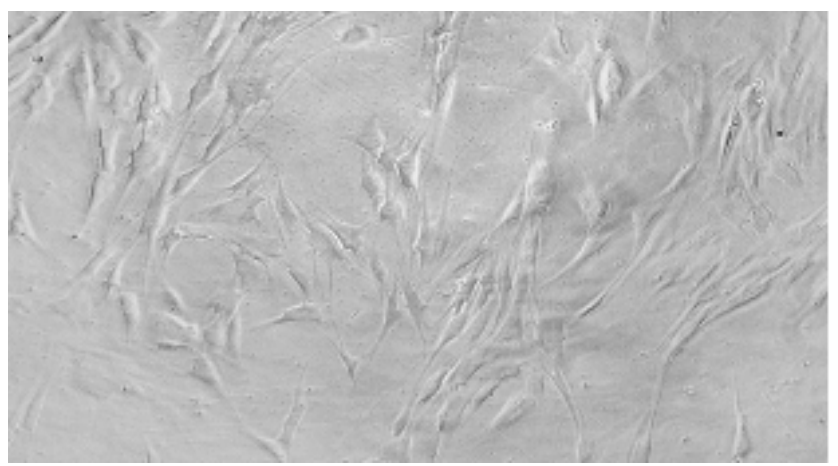

(a)

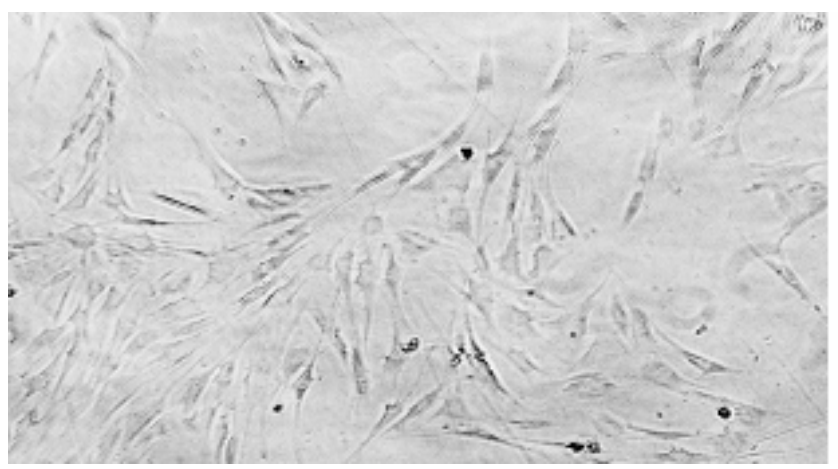

(c)

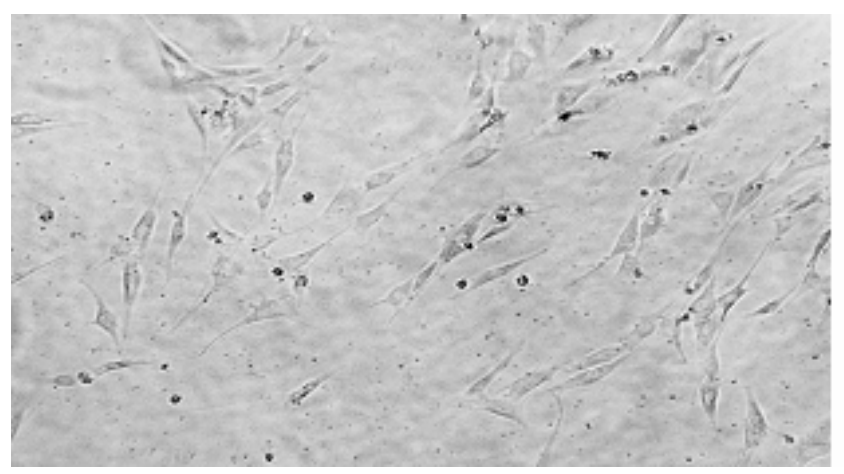

(e)

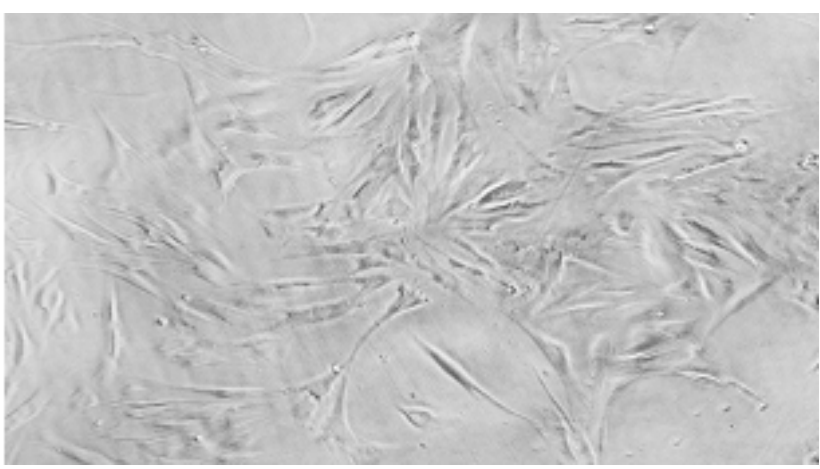

(b)

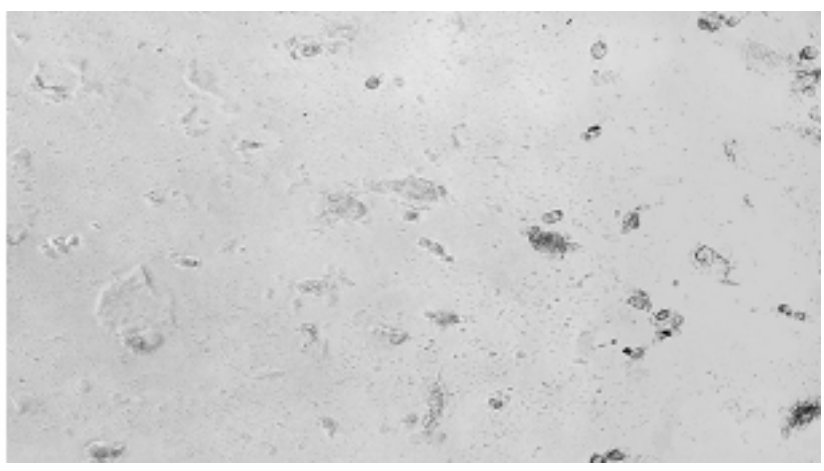

(d)

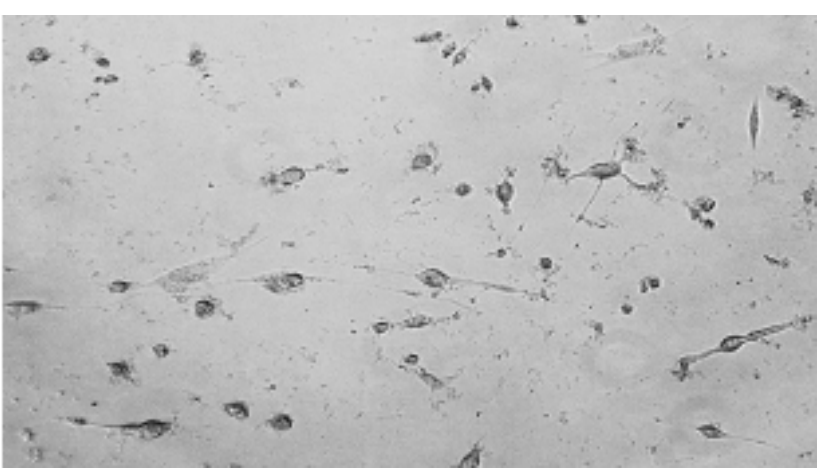

(f)

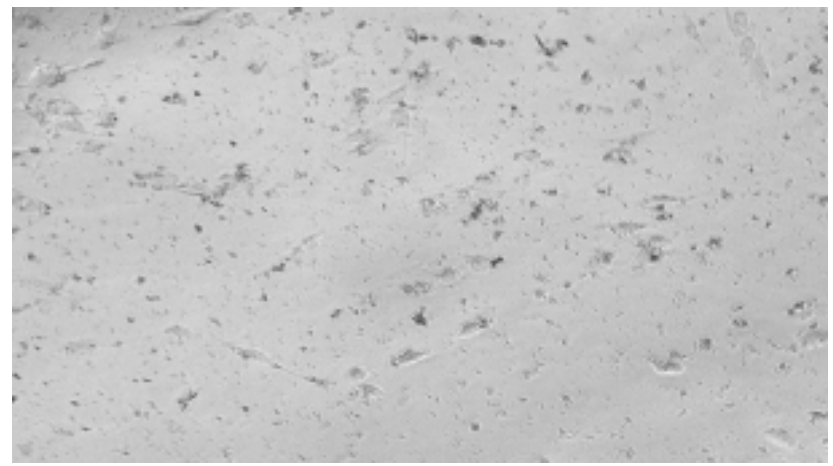

(g)

Figure 5. HPC morphology and density (100X magnification). (a) HPC; (b) Fuji II; (c) Fuji II LC; (d) Vitremer; (e) P60; (f) Z100; (g) Durelon. Cell morphology photomicrograph was obtained after the cells incubated with the 7-day eluates for $72 \mathrm{~h}$. 


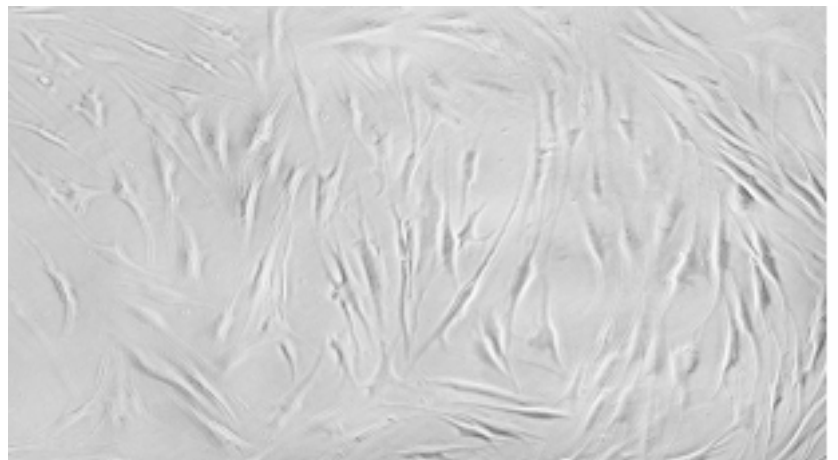

(a)

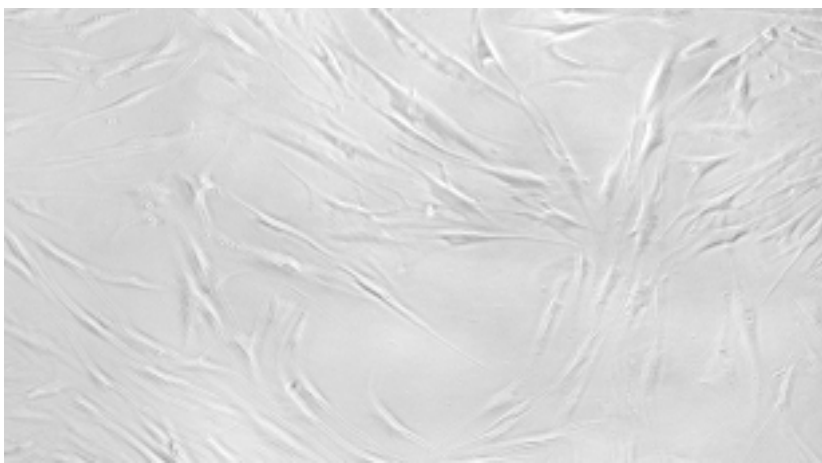

(c)

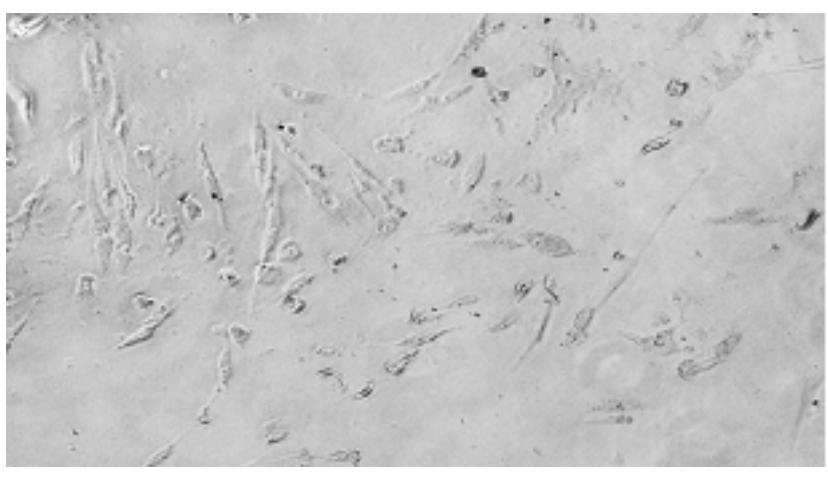

(e)

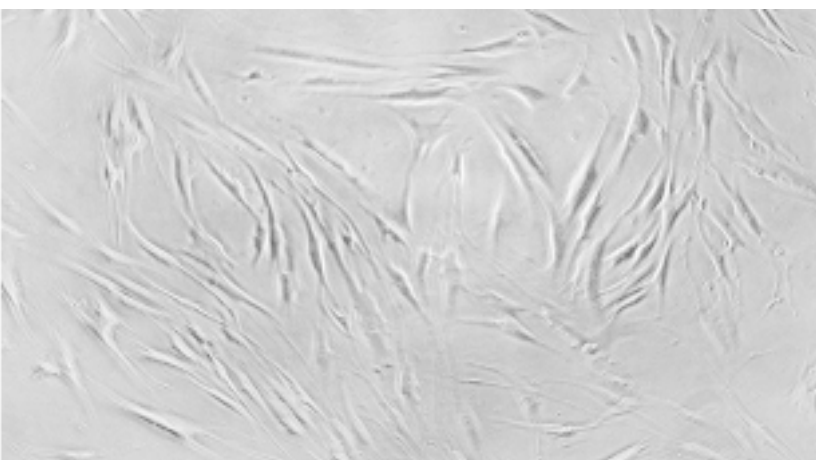

(b)

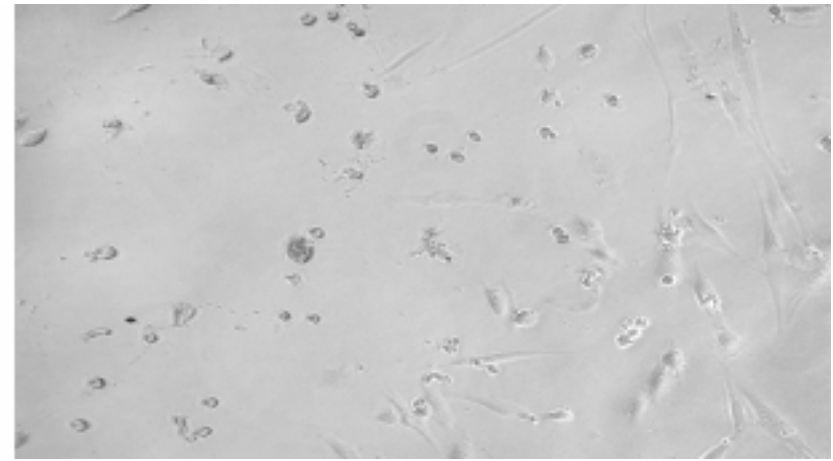

(d)

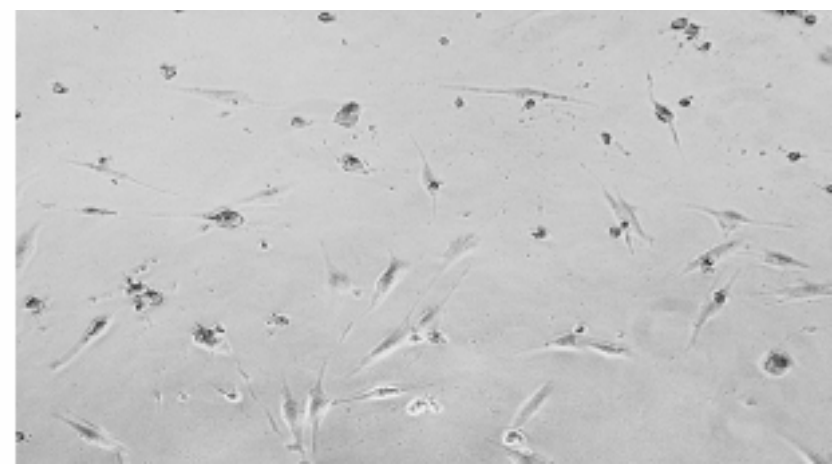

(f)

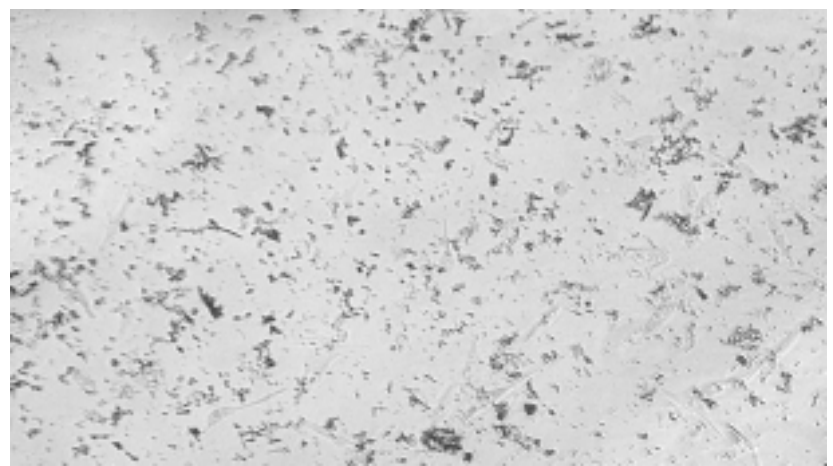

(g)

Figure 6. HGF morphology and density (100X magnification). (a) HPC; (b) Fuji II; (c) Fuji II LC; (d) Vitremer; (e) P60; (f) Z100; (g) Durelon. Cell morphology photomicrograph was obtained after the cells incubated with the 7-day eluates for $72 \mathrm{~h}$. 


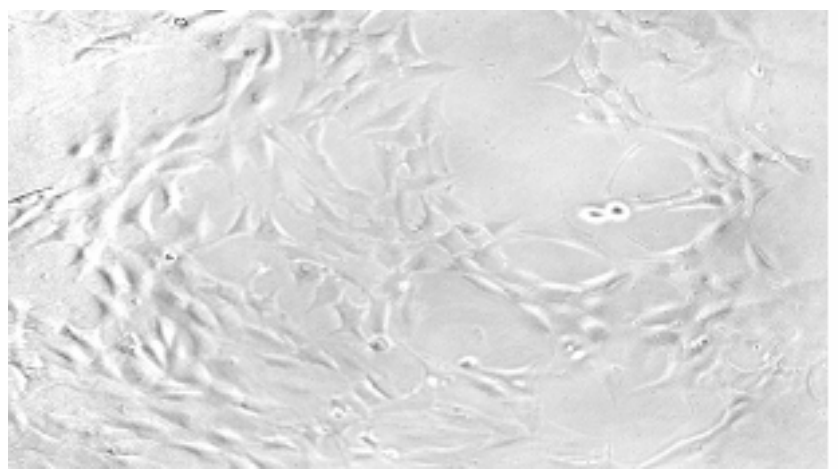

(a)

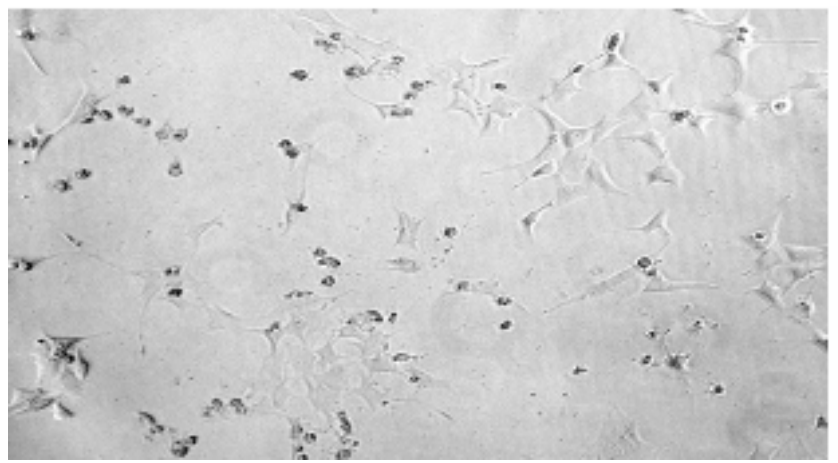

(c)

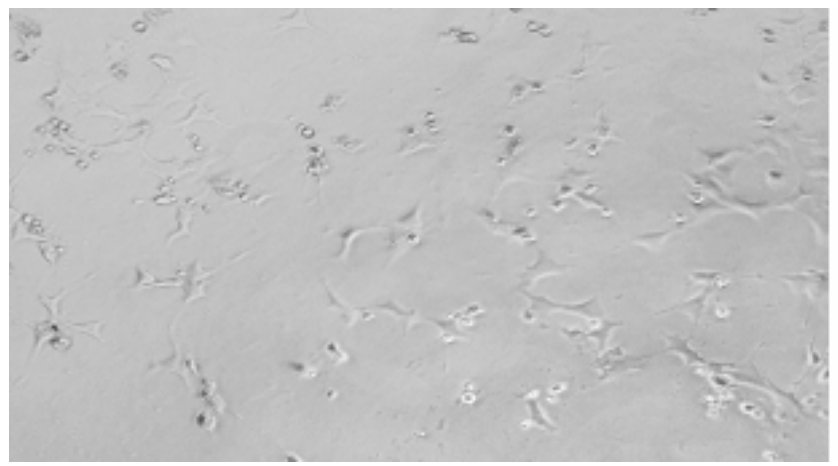

(e)

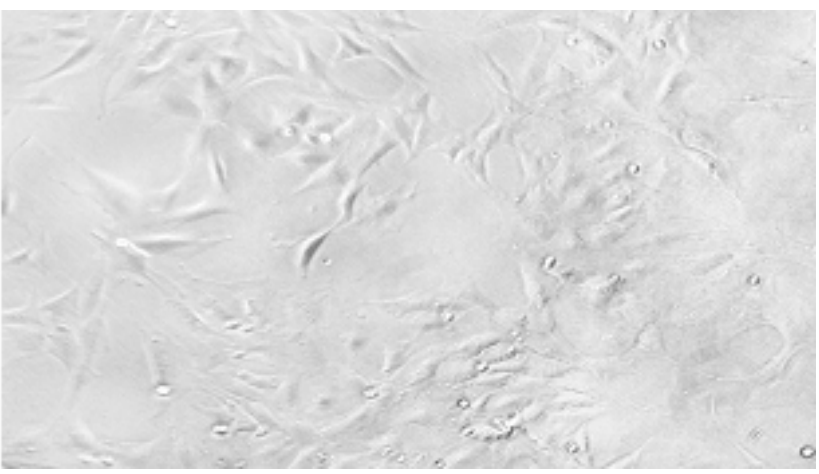

(b)

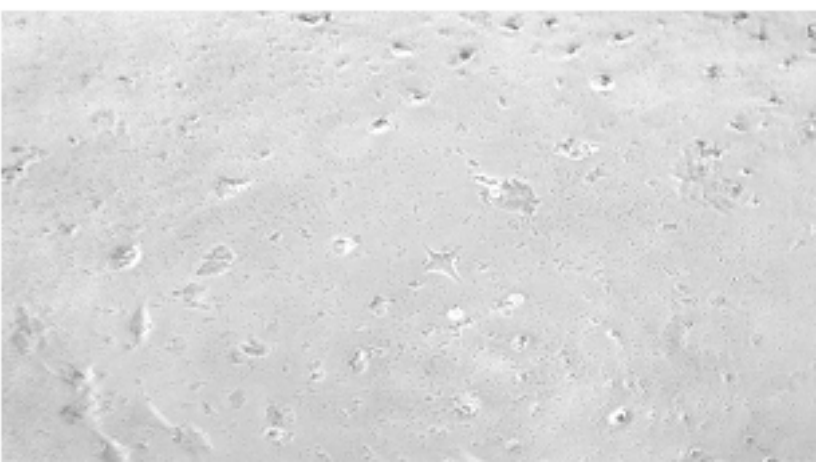

(d)

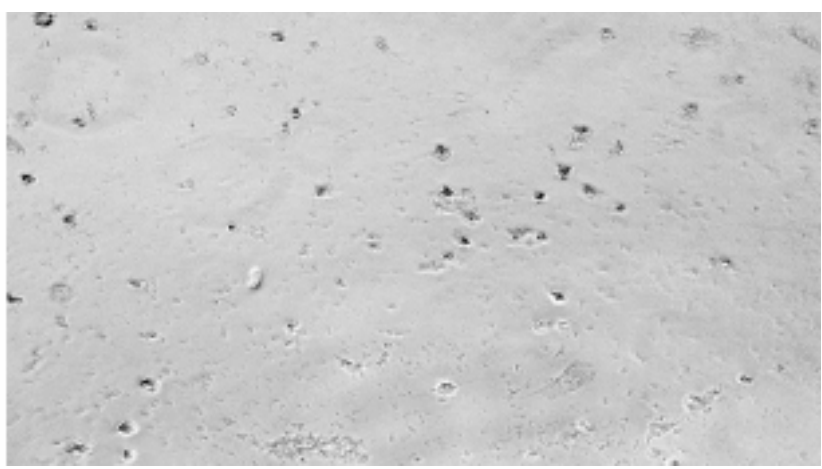

(f)

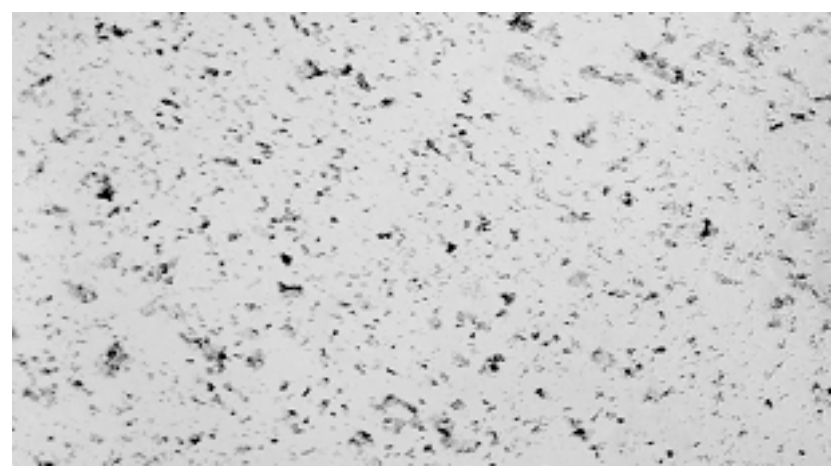

(g)

Figure 7. 3T3 fibroblast morphology and density (100X magnification). (a) HPC; (b) Fuji II; (c) Fuji II LC; (d) Vitremer; (e) P60; (f) Z100; (g) Durelon. Cell morphology photomicrograph was obtained after the cells incubated with the 7-day eluates for 72 h. 
(Vitremer), (f) (Z100) and (g) (Durelon), large black spots (condensed irregular nuclei of the dead cells) are clearly seen and the intact cells disappeared. Furthermore, the lysed cell pieces are found in Figure 5(g).

Figure 6 is a set of optical photomicrographs describing the HGF morphology after contact with the corresponding 7-day eluate. The results are very similar to those shown in Figure 5, except that the healthy HGFs look more elongated than healthy HPCs. Furthermore, more lysed cell pieces are observed in Figure 6(g).

Figure 7 is a set of optical photomicrographs describing the $3 \mathrm{~T} 3$ cell morphology after contact with the corresponding 3-day eluate. In Figures 7(a) (control) and (b) (Fuji II), numerous cells with a multipolar shape (typical 3T3 cell morphology) are observed. In Figures 7(c) (Fuji II LC) and (e) (P60), black spots (dead cells) and deformed $3 \mathrm{~T} 3$ cells are clearly seen, although the multipolar-shaped cells are still noticed. In Figures 7(d) (Vitremer) and (f) (Z100), nearly no multipolar-shaped cells are observed except for the round dead cells. In Figure 7(g), the cells are found to be significantly lysed and different sizes of black spots or lysed pieces are noticed everywhere.

From the above photomicrographs, it is clear that the results for cell morphology matched the results shown for the cell viability and well explained the cell viability values described in Figure 1.

\section{Conclusions}

In vitro cytotoxicity of six commercial dental filling restoratives on human pulp cells (HPCs) and human gingival fibroblasts (HGFs) were tested using WST-1 assay. Continuous $3 \mathrm{~T} 3$ mouse fibroblast cell lines were used for comparison. The results show that conventional glassionomer cement (GIC) Fuji II is not cytotoxic to all the cells. Resin-modified GIC (RMGIC) Fuji II LC is not cytotoxic to both HPCs and HGFs but cytotoxic to 3T3 cells. RMGIC Vitremer and resin composite Z100 are very cytotoxic to all the cells. Resin composite P60 is cytotoxic but much less cytotoxic than Z100. Dental cement Durelon is the most cytotoxic among the six tested materials. It was found that continuous $3 \mathrm{~T} 3$ cell lines were more vulnerable to leachable cytotoxic components than human primary HPCs and HGFs. It was also found that the cytotoxcity of the tested materials was dose-dependent. This study reports the in vitro responses of human primary pulp and gingival cells as well as continuous 3T3 mouse fibroblasts to six commercial dental filling restoratives. The in vivo tissue responses in animals or human to these materials might be different. Therefore, it would be necessary if some in vivo animal study could be done with these restoratives before making a final conclusion, i.e., whether these materials are in vivo cy- totoxic or in other words whether the tissues are tolerable to the leachable components in vivo.

\section{Acknowledgements}

This work was partially sponsored by NIH challenge grant (RC1) DE020614.

\section{REFERENCES}

[1] K. C. Modena, L. C. Casas-Apayco, M. T. Atta, C. A. Costa, J. Hebling, C. R. Sipert, M. F. Navarro and C. F. Santos, "Cytotoxicity and Biocompatibility of Direct and Indirect Pulp Capping Materials," Journal of Applied Oral Science, Vol. 17, No. 6, 2009, pp. 544-54. doi:10.1590/S1678-77572009000600002

[2] G. L. Polyzois, "In Vitro Evaluation of Dental Materials," Clinical Materials, Vol. 16, No. 1, 1994, pp. 21-60. doi:10.1016/0267-6605(94)90088-4

[3] J. W. Nicholson and B. Czarnecka, "The Biocompatibility of Resin-Modified Glass-Ionomer Cements for Dentistry," Dental Materials, Vol. 24, No. 12, 2008 pp. 17021708. doi:10.1016/j.dental.2008.04.005

[4] W. Spahl, H. Budzikiewicz and W. Geurtsen, "Determination of Leachable Components from Four Commercial Dental Composites by Gas and Liquid Chromatography/ Mass Spectrometry," Journal of Dentistry, Vol. 26, No. 2, 1998 , pp. 137-145. doi:10.1016/S0300-5712(96)00086-3

[5] A. Hensten-Pettersen, "Skin and Mucosal Reactions Associated with Dental Materials," European Journal of Oral Sciences, Vol. 106, No. 2, 1998, pp. 707-712.

[6] W. Geurtsen, W. Spahl and G. Leyhausen, "Residual Monomer/Additive Release and Variability in Cytotoxicity of Light-Curing Glass-Ionomer Cements and Compomers," Journal of Dental Research, Vol. 77, No. 12, 1998, pp. 2012-2019.

doi: $10.1177 / 00220345980770121001$

[7] C. T. Hanks, S. E. Strawn, J. C. Wataha and R. G. Craig, "Cytotoxic Effects of Resin Components on Cultured Mammalian Fibroblasts," Journal of Dental Research, Vol. 70, No. 11, 1991, pp. 1450-1455. doi:10.1177/00220345910700111201

[8] Y. Issa, D. C. Watts, P. A. Brunton, C. M. Waters and A. J. Duxbury, "Resin Composite Monomers Alter MTT and LDH Activity of Human Gingival Fibroblasts in Vitro," Dental Materials, Vol. 20 No. 1, 2004, pp. 12-20. doi:10.1016/S0109-5641(03)00053-8

[9] J. C. Wataha, F. A. Rueggeberg, C. A. Lapp, J. B. Lewis, P. E. Lockwood, J. W. Ergle and D. J. Mettenburg, "In Vitro Cytotoxicity of Resin Containing Restorative Materials after Aging in Artificial Saliva," Clinical Oral Investigations, Vol. 3, No. 3, 1999, pp. 144-149. doi: $10.1007 / \mathrm{s} 007840050093$

[10] R. Pulgar, M. F. Olea-Serrano, A. Novillo-Fertrell, A. Rivas, P. Pazos, V. Pedraza, J. M. Navajas and N. Olea, "Determination of Bisphenol A and Related Aromatic Compounds Released from Bis-GMA-Based Composites 
and Sealants by High Performance Liquid Chromatography," Environmental Health Perspectives, Vol. 108, No. 1, 2000, pp. 21-27. doi:10.1289/ehp.0010821

[11] M. Kaga, M. Noda, J. L. Ferracane, W. Nakamura, H. Oguchi and H. Sano, "The in Vitro Cytotoxicity of Eluates from Dentin Bonding Resins and their Effect on Tyrosine Phosphorylation of L929 Cells," Dental Materials, Vol. 17, No. 4, 2001, pp. 333-339. doi:10.1016/S0109-5641(00)00091-9

[12] W. Geurtsen, "Biocompatibility of Resin-Modified Filling Materials," Critical Reviews in Oral Biology and Medicine, Vol. 11, No. 3, 2000, pp. 333-355. doi:10.1177/10454411000110030401

[13] R. G. Craig, "Restorative Dental Materials," 10th Edition, Mosby-Year Book, Inc., St Louis, 1997.

[14] N. Moszner and U. Salz, "New Developments of Polymeric Dental Composites," Progress in Polymer Science, Vol. 26, No. 4, 2001, pp. 535-576. doi:10.1016/S0079-6700(01)00005-3

[15] M. Z. A. M. Sulong and R. A. Aziz, "Wear of Materials Used in Dentistry: A Review of the Literature," The Journal of Prosthetic Dentistry, Vol. 63, No. 3, 1990, pp. 342349. doi:10.1016/0022-3913(90)90209-U

[16] C. A. Quinlan, D. M. Zisterer, K. F. Tipton and M. I. O'Sullivan, "In Vitro Cytotoxicity of a Composite Resin and Compomer," International Endodontic Journal, Vol. 35, No. 1, 2002, pp. 47-55. doi:10.1046/j.1365-2591.2002.00456.x

[17] I. A. Mjor, "Current Views on Biological Testing of Restorative Materials," Journal of Oral Rehabilitation, Vol. 17, No. 6, 1990, pp. 503-507. doi:10.1111/j.1365-2842.1990.tb01421.x

[18] B. Thonemann, G. Schmalz, K. A. Hiller and H. Schweikl, "Responses of L929 Mouse Fibroblasts, Primary and Immortalized Bovine Dental Papilla-Derived Cell Lines to Dental Resin Components," Dental Materials, Vol. 18, No. 4, 2002, pp. 318-323. doi:10.1016/S0109-5641(01)00056-2

[19] D. Xie, Y. Yang, J. Zhao, J. G. Park and J. T. Zhang, “A Novel Comonomer-Free Light-Cured Glass-Ionomer System for Reduced Cytotoxicity and Enhanced Mechanical Strength," Dental Matererials, Vol. 23, No. 8, 2007, pp. 994-1003. doi:10.1016/j.dental.2006.09.001

[20] J. C. Wataha, F. A. Rueggeberg, C. A. Lapp, J. B. Lewis, P. E. Lockwood, J. W. Ergle and D. J. Mettenburg, "In Vitro Cytotoxicity of Resin-Containing Restorative Materials after Aging in Artificial Saliva," Clinical Oral Investigations, Vol. 3, No. 3, 1999, pp. 144-149. doi:10.1007/s007840050093

[21] K. Wisithphrom, P. E. Murray and L. J. Windsor, "Interleukin-1 Alpha Alters the Expression of Matrix Metalloproteinases and Collagen Degradation by Pulp Fibroblasts," Journal of Endodontics, Vol. 32, No. 3, 2006, pp. 186-192. doi:10.1016/j.joen.2005.10.055

[22] J. Zhou and L. J. Windsor, "Porphyromonas Gingivalis Affects Host Collagen Degradation by Affecting Expression, Activation, and Inhibition of Matrix Metallopro- teinases," Journal of Periodontal Research, Vol. 41, No. 1, 2006, pp. 47-54. doi:10.1111/j.1600-0765.2005.00835.x

[23] H. Tominaga, M. Ishiyama, F. Ohseto, K. Sasamoto, T. Hamamoto, K. Suzuki and M. Watanabe, "A Water- Soluble Tetrazolium Salt Useful for Colorimetric Cell Viability Assay," Analytical Communications, Vol. 36, 1999, pp. 47-50. doi:10.1039/a809656b

[24] E. C. Lönnroth and J. E. Dahl, "Cytotoxicity of Liquids and Powders of Chemically Different Dental Materials Evaluated Using Dimethylthiazol Diphenyltetrazolium and Neutral Red Tests," Acta Odontologica Scandinavica, Vol. 61, No. 1, 2003, pp. 52-56.

[25] A. M. Aranha, E. M. Giro, P. P. Souza, J. Hebling and C. A. de Souza Costa, "Effect of Curing Regime on the Cytotoxicity of Resin-Modified Glass-Ionomer Lining Cements Applied to an Odontoblast-Cell Line," Dental Materials, Vol. 22, No. 9, 2006, pp. 864-869. doi:10.1016/j.dental.2005.11.015

[26] L. Stanislawski, X. Daniau, A. Lauti and M. Goldberg, "Factors Responsible for Pulp Cell Cytotoxicity Induced by Resin-Modified Glass Ionomer Cements," Journal of Biomedical Materials Research, Vol. 48, No. 3, 1999, pp. 277-288.

doi:10.1002/(SICI)1097-4636(1999)48:3<277::AID-JBM 11>3.0.CO;2-T

[27] N. C. Beriat, A. A. Ertan, S. Canay, A. Gurpinar and M. A. Onur, "Effect of Different Polymerization Methods on the Cytotoxicity of Dental Composites," European Journal of Dentistry, Vol. 4, No. 3, 2010, pp. 287-292.

[28] C. J. Kleverlaan and A. J. Feilzer, "Polymerization Shrinkage and Contraction Stress of Dental Resin Composites," Dental Materials, Vol. 21, No. 12, 2005, pp. 11501157. doi:10.1016/j.dental.2005.02.004

[29] Y. Momoi, K. Hirosaki, A. Kohno and J. F. McCabe, "Flexural Properties of Resin-Modified "Hybrid" GlassIonomers in Comparison with Conventional Acid-Base Glass-Ionomers," Dental Materials Journal, Vol. 14, No. 2, 1995, pp. 109-119.

[30] M. Schmid-Schwap, A. Franz, F. Konig, M. Bristela, T. Lucas, E. Piehslinger, D. C. Watts and A. Schedle, "Cytotoxicity of Four Categories of Dental Cements," Dental Materials, Vol. 25, No. 3, 2009, pp. 360-368. doi:10.1016/j.dental.2008.08.002

[31] D. Xie, M. Faddah and J. G. Park, "Novel Amino Acid Modified Zinc Polycarboxylates for Improved Dental Cements," Dental Materials, Vol. 21, No. 8, 2005, pp. 739748. doi:10.1016/j.dental.2005.01.008

[32] A. D. Wilson and J. W. McLean, "Glass-ionomer Cements," Quintessence Publ Co., Chicago, 1988.

[33] J. W. Nicholson, J. H. Braybrook and E. A. Wasson, "The Biocompatibility of Glass-Poly(Alkenoate) (Glass-Ionomer) Cements: A Review," Journal of Biomaterials Science, Polymer Edition, Vol. 2, No. 4, 1991, pp. 277-285. doi:10.1163/156856291X00179

[34] E. A. Wasson and J. W. Nicholson, "Change in pH during Setting of Polyelectrolyte Dental Cements," Journal of 
Dentistry. Vol. 21, No. 2, 1993, pp. 122-126.

doi:10.1016/0300-5712(93)90161-I

[35] J. Borovansky and P. A. Riley, "Cytotoxicity of Zinc in Vitro," Chemico-Biological Interactions, Vol. 69, No. 2-3, 1989, pp. 279-291. doi:10.1016/0009-2797(89)90085-9

[36] L. Stanislawski, X. Daniau, A. Lauti and M. Goldberg, "Factors Responsible for Pulp Cell Cytotoxicity Induced by Resin-Modified Glass Ionomer Cements," Journal of Biomedical Materials Research, Vol. 48, No. 3, 1999, pp. 277-288.

doi:10.1002/(SICI)1097-4636(1999)48:3<277::AID-JBM $\underline{11>3.0 . \mathrm{CO} ; 2-\mathrm{T}}$ 